\title{
Introduction: Situating Power in Dynamics of Securitization
}

\author{
Andreas Langenohl and Regina Kreide
}

\section{Contextualization and outline of the volume}

Today, 'security' has advanced to a conception that is equally prominent in social and political discourses and practices, and in academe. Contemporary diagnoses as well as historical reconstructions of security dynamics point out that 'security' has evolved as a vernacular conception whose reference dimension is constantly widening, up to a point where it appears without qualifier, but as a value in itself. For instance, it has been argued that security, once the prerogative of the modern state and its raison d'état, is meanwhile framed as a concern that transcends the interests, but also the boundaries and capacities, of the state. Developments like the expansion of 'security', as a normative demand, to the realm of society and to individuals' safety, as in the conception of 'human security', tend to posit state-political interests in security in contradistinction to the wellbeing of social groups and societal systems of reproduction as well as to the safety of individuals irrespective of their political belonging. ${ }^{1}$ In such constellation, the conception of 'security' loses its seemingly self-explicatory quality, instead becoming a key vehicle for negotiations and fights over political prerogatives, social demands, and claims at cultural identities. Frédéric Gros has reconstructed some aspects of this generalization of 'security', arguing that while 'security' has a quite diverse and complicated genealogy in Western European history, it has meanwhile become a global currency whose prominence resides precisely in the conspicuous absence of any qualifier of what 'security' is concretely supposed to mean, and for whom. ${ }^{2}$ In particular, the notion of 'human security', according to Gros, serves as a vehicle for a bio-political conception of individuals as carriers of life functions that replaces the idea of individuals as holders of human rights. ${ }^{3}$ These accounts highlight the ubiquity, and at the same time vague-

1 Daase 2011, 2012; Junk 2011.

2 Gros 2015; see also Browning/McDonald 2011.

3 Gros 2015, pp. 185-255. 
ness, of 'security' as the base of the power of that conception. 'Security' seems to have lost all substantial qualifiers to the advantage of a negativistic conception, namely, as the absence of threat. In some languages, this negativistic definition of security even materializes on the word-morphological level, like in the Russian bezopasnost', which literally means 'the absence of danger/threat'.

Accordingly, security-related research has focused for some time now on those processes that boost the categorization of social and political constellations as relevant to security - that is, as harboring potential threats to a community or a polity. Thereby, it has been, in particular, International Relations and Strategic Studies which have become a platform for such conceptualizations of security. Since the 1980s, 'Securitization Studies' has emerged, and internally differentiated, as the "largest body of secondary literature in security studies". ${ }^{4}$ It rejects the realism inherent in classical understandings of IR, in particular the stipulation that states have 'natural' security prerogatives that organize their behavior within an anarchic international system in which each shift in power can only end up in a zero-sum game. Instead, scholars maintain that security issues are politically and socially constructed. In this context, the term of 'securitization' has emerged as a key concept for the reconstruction of those processes that frame given policy issues and social constellations as relevant for a polity's survival. ${ }^{5}$ Since then, 'securitization' has been conceptualized in various ways. ${ }^{6}$ Starting from the speech act-theoretical model of the 'Copenhagen School' and being amended by more practice-theoretical approaches $^{7}$, it meanwhile transcends the focus on polities, instead posing questions concerning the securitization of social groups, transnational networks (for instance, such as terrorism), or economic developments. ${ }^{8}$

This volume contributes to this debate through a rigorous focus on the power dimension of securitization. Thereby, it follows a dual strategy. On the one hand, it discusses recent developments in securitization studies from the angle of how notions of power figure in these debates. In this respect, the volume's contribution consists both in a systematization of the debate and in the suggestions of conceptual and theoretical approaches

4 Christou et al. 2010: 348.

5 Wæver 1995; 1996; cf. Vuori 2011.

6 See Wæver 2004 and 2015, Buzan 2016.

7 Bigo 2002, 2006; 2014; Balzacq 2005, 2011; Balzacq et al. 2016; Leander 2010.

8 See, for a summary of recent research trends, Balzacq et al. 2016. 
that might benefit the debate, given the circumstance that a broad effort to conceptually come to terms with the power in securitization processes is absent so far. On the other hand, the volume aims at a more historical and interdisciplinary contextualization of conceptions of power in securitization studies through exemplarily focusing on scenes of securitization, taking up the thread in the $18^{\text {th }}$ century. The contributions thus span the range not only of political science, sociology and anthropology from which prominent conceptual contributions to securitization studies have emerged, but also of law, arts history, contemporary history, and social history.

By dint of its historical and conceptual approach, the volume aims also at questioning certain core assumptions in securitization studies as they present themselves today. Securitization studies started out by questioning the ontological dignity of the category of 'security' as used in realist International Relations and Strategic Studies, ${ }^{9}$ thereby also conveying critiques of the potentially detrimental uses of security as a vehicle of political dramatization. ${ }^{10}$ However, securitization studies found it less easy to leave behind other core characteristics of IR. This pertains, in particular, to two of its aspects which are crucial to the realist understanding of state power in the international system: the state and the international system. Securitization, while having broadened its horizon to scales of securitization different from the state (for instance, 'macro-securitizations'), ${ }^{11}$ many of its scholars still prefer to direct their attention to the securitization of the state vis-à-vis threats to that state as they are being constructed within the horizon of the international system (see Andreas Langenohl's paper in this volume).

The most powerful critique of such state-centrism has, arguably, come from anthropology, which has recently fostered an approach that views processes of securitization as a basic mode of the reproduction of any collectivity in the sense of its production and stabilization over time. ${ }^{12}$ According to this approach, the invocation of security is a powerful lever in the symbolic, social, and political constitution of collectivities; as such, collectivities can never be regarded as 'given'. Moreover, securitization constructs communities and entities not only through framing them as be-

9 See for an historical overview Wæver 2015.

10 See for a discussion Browning/McDonald 2011.

11 Cf. Buzan/Wæver 2009.

12 Holbraad/Pedersen 2013; cf. critically Rollason 2017. 
ing under threat, but also through asserting that other communities and entities are potentially threatening (see Regina Kreide's and Carola Westermeier and Hannah Broecker's articles). Finally, the 'international system' purports an understanding of principal symmetry and zero-sum logics between the units that comprise it, thus tending to turn a blind eye to structurally caused asymmetries within that system, for instance, in (post-)colonial dynamics (see Maria Ketzmerick's contribution).

While this volume, therefore, presents anthropological, sociological and political-theoretical critiques of views on securitization that still seem to take the state and the international system for granted, it also includes studies that question the saliency of the state and the international system from an historical point of view. While studies on security and securing have been common in historiography, for instance, in military and diplomatic history, the historical perspectivation of securitization studies is still in a very early, but promising phase. ${ }^{13}$ Thereby, the historical reconstructions of securitization dynamics assembled in this volume aim not so much at an outright rejection of the 'modernism' inherent in IR and also in some strands of securitization studies, but rather at the productive engagement with dynamics of securitization, and the power dimensions inherent in them, through focusing on such dynamics that escape the logic of the state as contained within an 'anarchic' international system. Examples range from securitization discourses and practices in early modern municipalities and cities in the $19^{\text {th }}$ and $20^{\text {th }}$ centuries to the role of international public law as a securitizing force that was set up to challenge the international system's 'anarchy', to securitization dynamics within asymmetrical transnational constellations, like in the context of decolonization movements.

This way, the volume dedicates itself to opening up a discussion over possibilities to conceptualize power dynamics in securitization processes beyond the state and the international system. In the following, we will briefly introduce the volume's contributions along the lines of conceptual arguments that crosscut them. The articles are organized into two book sections. While the first represents conceptual attempts to deepen our understanding of the power dimension of securitization processes, the second one comprises articles which, in conceptualizing that power dimension, in-

13 Buzan/Wæver 2009; Buzan 2016; Conze 2012. 
troduce views on securitization that bypass and challenge the nexus of state and international system.

\section{Part I-Conceptualizing the power dimensions of securitization}

Arguably, any discussion of power in securitization processes is inextricably linked with questions of how power is conceptualized in general, and which kind of power securitization represents. The Copenhagen School has given some impulse to debating that question. For instance, the CS has been read as being based on a Schmittian conception of power, so that the 'securitizing move' embodies the sovereign declaration of a state of exception. ${ }^{14}$ Other critics have seen the CS as rather shuttling between a Schmittian and a Habermasian aspect of securitization: As the 'securitizing move', it was argued, needs to be validated by relevant 'audiences', there is in principle (at least, within democratic and pluralist political orders) the chance to confront the securitizing move with questioning and resistance. ${ }^{15}$ Other contributions reframed the CS argument as relating to a rather discursive mode of power: The "grammar of security"16 invoked by the securitizing actors, according to this view, represents a discursive mode of power that responds to the reflexive contingency of modern societies, in that it processes that contingency through a violent transformation into a juxtaposition of self and other. ${ }^{17}$ The discursive model of power, in turn, has been supplemented by the question of how actors maneuver strategically within discourse. ${ }^{18}$ Approaches delineating themselves from the CS, like the Paris School, have conceptualized power as residing rather in social relations structuring the dynamics between securitizing actors and their audiences: "The practical force of discourse falls, therefore, between logical consistency and the dynamics of social power". ${ }^{19}$ So far, however, the debate has not resulted in a clear positing of alternatives regarding how to conceptualize power in securitization. In particular, the relationship that securitization studies maintains with resource-theoretical

14 Munster 2005.

15 Williams 2003.

16 Buzan et al. 1998, p. 33.

17 Huysmans 1998.

18 Stritzel 2012.

19 Balzacq 2011, p. 26. 
and instrumental conceptions of power - a power that is possessed by an actor strategically pursuing his or her interests - is still unresolved (see Langenohl in this volume).

The contributions in the first section of this volume maintain that resource-theoretical and instrumental conceptions of power in securitization are comparatively weak. As securitization is first of all a process of relating - that is, a process shaping, instigating and creating relations between and among actors, discourses, artefacts, and social and political figurations - resource-theoretical approaches find themselves at odds with this relational dynamic because they tend to isolate actors and their power bases. Pursuing this argument further, any relational notion of power cannot but establish a connection between political, social, symbolic and material processes. ${ }^{20}$ Processes of securitization may thus be perspectivized as dynamics that stabilize or destabilize such relations through a primary organizing principle, which is security and its respective understandings, shuttling between the invocation of a threatened entity and that of potential threat. Power, accordingly, resides in the capacity to streamline connectivities and collectivities according to the respectively pertaining logic of security and thus to produce or stabilize such connectivities and collectivities across the realms of the political, the social, the symbolic and the material.

Andreas Langenohl's paper dissects the securitization debate with a view to the different conceptions of power inherent in its contributions and strands, arguing that the question of how a notion of power can inform securitization studies cannot be decoupled from understandings of the political implicit in these currents. Within this horizon, the paper makes two main points. First, the Copenhagen School - especially Ole Wæver's work - is given credit for disentangling the notion of political power from the notion of securitization altogether. As the CS tends to diagnose the effects of securitization as the entering into potentially fatal dynamics such as declaring exceptional states, demanding extraordinary measures, and being bound to these states and decisions, securitization tends to strip securitizing actors of any capability to engage in political coordination, especially with those adversaries that are made to represent a threat to the polity. Thus, the CS invites the conceptualization of power not so much on the model of securitization, but rather on that of desecuritization, in the sense 
of a restoration of the capability to engage in more open-ended relationships, among antagonists and among allies. Second, and taking this argument further, the paper proposes a sociological variant of relational social theory - namely, Norbert Elias's sociology of figurations - in order to conceptualize the power dynamics in securitization. Most importantly, an analytical difference is introduced between the power to securitize - that is, the manifestation of a relational structure that encourages, enables, or demands securitization - and the power of securitization, in other words, the effects, often unintended, that securitization has on the conduct of political and social affairs.

In Chapter 3, Regina Kreide continues this discussion and engages in a philosophical debate about the power of border politics and its securitization effects. She demonstrates that the 'grammar of security' diagnosed by the CS is underpinned by the philosophical argumentation that aims at justifying 'security' as a legitimate concern in today's societies. Yet, upon closer inspection, these arguments are more instrumental in justifying political and social exclusion. She uses Andreas Langenohl's (in this volume) useful distinction between the "power to securitize" and the "power of securitization" to argue that if collectives of states mobilize their sovereignty to close borders and, thus, "appropriate" a right to exclude, they problematically transform our societies into securitized societies. In conversation with scholars of critical security studies, Kreide proposes considering the relationship between the power to securitize and that of securitization as a dialectical one, which - vis-à-vis arguments in favor of a right to exclude - reveals how the materialization of closing borders inherently negatively affects those who should be protected through rendering them, including the Roma, "irregular" and "illegal", and, thus, through fundamentally denying the guaranteeing of their fundamental citizenship rights.

Hannah Broecker's and Carola Westermeier's joint contribution proposes a hegemony-theoretical understanding of the power in securitization, viewing the invocation of 'security' and the constitution of asymmetrical relations between subject positions as flip sides of the same coin. According to this proposition, leaning toward the work of Ernesto Laclau and Chantal Mouffe, securitization effects connectivities and collectivities through the empty signifier of security, which effaces differences between the elements of the collectivity constituted as threatened as well as dramatizing distinctions between that collectivity and that which is supposed to be threatening it. Taking this theoretical stance further, the paper argues 
with a view to the dealing with the most recent financial crisis in the European Union that the securitization of 'financial stability' by political actors eventually gave way to a discursive deflation of the financial economy as primary root of the crisis as a result of a delegation of the financial problematics to expert commissions. The paper thus makes a case for an understanding of power in securitization that does not stop short at an analysis of the securitizing move, but investigates how that move enters into discursive dynamics that, rather inconspicuously, turn the tables on the securitizing actors. In the case under discussion, the empty signifier of 'financial stability' was relocated from a discourse that securitized financial markets as a threat to the polity (the European Union) into a discourse that construed financial markets as the referent object of securitization. ${ }^{21}$

Carola Dietze, in her chapter, discusses the relevance of considerations of political (de-)legitimation in a broad sense for processes of securitization. Interestingly, critical security studies have so far discussed the legitimacy of political orders as such only tangentially, instead narrowing the focus on the legitimation of securitizing actors and security professionals. Dietze takes issue with this view on the example of debates around political (de-)legitimation triggered by terrorism as a new tactic of political violence. In particular, she analyzes claims to responsibility and other sources issued by some of the $19^{\text {th }}$ century's first terrorists. Security concerns and the viability of modern states, Dietze thus shows, are intrinsically linked to each other. She concludes her chapter with a suggestion to include the category of political legitimacy in a more comprehensive way into securitization studies.

\section{Part II - Historical and contemporary manifestations of the power dynamics in securitization}

The articles in this section demonstrate that the power in securitization, from a historical perspective, cannot be reduced to the securitization of the polity as a given entirety - a stipulation inherent in some strands of securitization theory that presuppose the state and its structures of authorization in order to model securitization as an actualization of the 'grammar of se-

21 Cf. Wæver 1995. 
curity' in the first place. ${ }^{22}$ The 'entirety' of the polity, or of any other entity that is made into the referent object of securitization, is not given but needs to be symbolically, politically and socially manifested. Seen from this angle, the recent diagnosis of an enlargement of the horizon of securitization from state to society and to the individual ${ }^{23}$ merits historical reconsideration, because it was never the state or the polity per se that became objects of securitization - rather, state and polity are referent objects of securitization that require symbolic work for their constitution.

The sheer institutional existence of states, as well as the focus of securitization studies on democratic political orders (cf. Dietze's contribution), has often tended to camouflage the construction work necessary to constitute the referent objects of securitization. It is, hence, smaller-scale entities, like cities and social groups, within them which are beneath the state and polity level that can become the object of security concerns, both in the form of constructed referent objects and as constructed threats (see the contributions by Krüger and Lenger, Haus, and Ivasiuc). Here, the symbolic-political, but also material, work of securitization becomes aptly observable because the nexus between those groups, often tiny in number, and the overall security concerns of the community, society and polity is based on symbolic inflation, dramatization, and material stakes. Also, these articles show that the local dynamics of securitization lend themselves to being scrutinized through Foucauldian categories of power, such as pastoral, disciplinary or governmental power, which enter into complex synchronicities.

Historical study also demonstrates that the international ramifications of power dimensions in securitization require a much more cautious reconstruction than the all-out instrumentalist approach of realist IR, which still seems to infiltrate securitization studies inasmuch they cling to an instrumentalist notion of power and the general heuristics of the international system (see Langenohl in this volume). The 'international' cannot be reduced to an anarchic inter-state system producing zero-sum struggles for hegemony, but fashions complications. For instance, considerations of how international law intervened in processes of securitization opens a view to the construction of security agendas beyond the nation-state level (see Thilo Marauhn's article). Conversely, securitization processes in post-

22 See Balzacq's 2005 critique.

23 Daase 2011, 2012. 
colonial transitions highlight the structurally unequal relationship between (former) metropolises and (former) colonies (see Maria Ketzmerick's contribution).

Lastly, a historical perspective is also able to establish that the power dimension of securitization does not necessarily reside in strictly timebound speech acts or practices, but may intrude into the symbolic inventory of society. Images and imaginations of peace and order may be, in fact, undergirded by a securitizing appeal to the porousness and preliminarity of such peace and order (see Katharina Krause's contribution). The conceptual consequence is that the line between 'ordinary politics' and the 'securitizing move' might be harder to establish than envisaged by the Copenhagen School. In other words, the 'grammar of security' might be rooted in, and handed over by, symbolical representations and material artefacts that reference not squarely threat but rather the desirability of 'ordinary' order against the horizon of its imagined sophistication that equals its imagined fragility.

Sebastian Haus' paper deals with the ways that drug users in public spaces in Frankfurt am Main became the object of governance by the city administration from the 1970s to the 1990s. He argues that the city's antidrug politics - which at times involved massive securitizing moves and measures, such as demands to hospitalize drug users and to ban them from public spaces - war repeatedly rearranged in connection, first, with public discourses about the threats that public drug use pose to 'public order', and second, with the emergence and spread of HIV and AIDS since the 1980s. Thus, the administration's take on drug policies was seldom unequivocal. The 1970s and 1980s were characterized by competing discourses framing drug use either as a security threat or, in a 'pastoral' sense sensu Foucault, as a threat to the users' wellbeing. With the advent of HIV and AIDS, this dual discourse gained complexity, as emerging self-help organizations of HIV-positive people, in close connection with the city's gay community, were able to reframe HIV and AIDS not as a matter of security or pastoral care, but as a matter of self-organized empowerment campaigns that highlighted the autonomy and agency of groups held to be at risk. The cooperation between these initiatives and the city administration was double-edged with respect to the balance of power: while gay men effectively resisted their securitization, and included heroin users in their cooperation with the city in the fight against HIV, 'liberal' modes of governing heroin users modelled after Foucault's notion of governmentality gained ground. The limits to this liberal governmentality came to the 
fore, however, with the effective dissolution of the public heroin scene in the city on the basis of renewed securitizing moves by the city administration at the beginning of the 1990s - a turn that the author interprets as pointing to the limits of governmental power, even in a place like Frankfurt which had 'reinvented' itself in a distinctively neoliberal style since the 1980s.

The article of Thilo Marauhn and Marie-Christin Stenzel argues that power, security, and public international law are closely interrelated. Juridification plays an important role in this relationship. The authors reveal an interesting interface between juridification and securitization, as juridification can be seen as an instrument that is adopted in order to address a situation of perceived insecurity. International law, like the climate summit or conventions against committing war are discussed examples. However, juridification does not allow for more security but may lead to a process of de-securitization. The authors define de-securitization as re-transferring issues back into the regular political processes. Public international law could then be perceived not only as a means of securitization but also as an instrument of de-securitizing. Putting this way, this legal approach offers a much broader conception of securitization than has been proposed by the Copenhagen School. ${ }^{24}$ The Copenhagen approach then appears to be too narrow for a comprehensive analysis of international negotiating processes. Looking at public international law through the lens of securitization helps to better understand, the authors argue, the interface between situational hermeneutics and instruments adopted in response to a situation defined as relevant in terms of security.

The joint paper by Christine Krüger and Friedrich Lenger engages in a social history of the securitization of dock workers' strikes and protests in the cities of London and Hamburg in the late $19^{\text {th }}$ century. The comparative view fleshes out the different stakeholders' interests as well as political and discursive strategies of the parties involved in those conflicts. Through the reconstruction of those dynamics, the Copenhagen School's model of securitization is complicated through a sociological analysis of the dynamics of bargaining and persuasive power. While in Hamburg, the strikes and protests faced a massive securitization through the discursive invocation of class struggle as a threat to the social order, with the state being called upon as the guarantor of security of last resort, in London a 
tendency prevailed that interpreted the strikes as the symptom of a social order in need of reform. On the conceptual level, the authors conclude that their comparison reveals two different articulations of security in the two cities. While the Hamburg scene lends itself to a CS-style analysis of securitization processes through dramatizing speech acts that are capable of inflating a class conflict into a security concern for the polity and for society (which, as a side effect, may result in path dependencies that restrict options of arbitration), the conflicts in London rather merit an analysis in terms of Foucault's notion of governmentality: The protests were taken up by the owners of the means of production and the local government as a call for social reform, equaling a de-securitization which has a governmental power dimension inasmuch as it is based on a vision of social forces regulating themselves, and that channels potential threats to the security of the societal system into organized negotiations. Security, in other terms, was not to be effected by a 'securitizing move' that would wield the powers of the sovereign state, but rather through a rearrangement of the potentially self-regulatory forces of social dynamics.

Katharina Krause's paper approaches the power dimension in securitization processes from the perspective of arts history. It poses the question how prints and image series in Nuremberg from the $16^{\text {th }}$ to the $18^{\text {th }}$ centuries portrayed the contemporary political and social order - and hence political legitimacy - through conveying a sense of threat that was, however, held in latency. In the images under investigation, this shows, for instance, through the portrayal of town fortifications which never move to the foreground but instead frame representations of a quiet and orderly life in the city and its vicinity. According to the author's interpretation, this ambivalently signals both a demonstration of political and administrative power and a reminiscence of earlier battles and wars, portraying the peaceful everyday as both orderly and exposed to a latent threat. And it is through this ambivalence and the durability conveyed to it by the visual representation that the images exert a distinct 'power of securitization' (cf. Langenohl's contribution), that is, a power that short-circuits the representation of political legitimacy and social order with the lasting allusion to a potential threat. Thus, the article contributes to deepening our understanding both of the constitution of the modern 'grammar of security' in the long term, and the share that visual representations - which are character- 
ized, according to Lene Hansen, ${ }^{25}$ by perceptual "immediacy", "circulability" across different contexts of perception and, as Krause's article clearly demonstrates, "ambiguity" - have in it.

Maria Ketzmerick's contribution is dedicated to an analysis of power dynamics of securitization in a period of decolonization, using the example of Cameroun in the 1950s. She looks at the power relations between the anti-colonial resistance movement, U.P.C., and the French administration in Cameroun under the umbrella of the UN trusteeship council, evolving and transforming in the course of a conflict in which various securitizing moves were taken by all parties involved. Moreover, securitization dynamics switched between different scales, from local to state and to suprastate levels, such as that of international organizations like the UN, which proved to be an effective projection screen and modulator of securitizing moves. Like in other recent contributions, ${ }^{26}$ the study shows that, from a historical perspective, the effects and the 'success' of securitizing moves cannot be understood without taking into account different audience structures on different scales and their interdependencies. The study also demonstrates the aptness of a notion of 'balance of power' as in Norbert Elias for the analysis of securitization processes, as it reconstructs how the different actors on different scales negotiated their positionalities and alliances.

Ana Ivasiuc suggests a framework for the analysis of power dimensions in securitization modelled after Actant Network Theory. According to her argument, which empirically relates to processes of securitization of social groups labelled 'nomadic' observed in the city of Rome, the still prevalent divide between the Paris School and the Copenhagen School has to be seen in the context of an overall epistemological impasse, critiqued by Latour, which results from the epistemological separation of symbolic meaning and material presence. Processes of securitization will thus only ever be partly understood in their complexity. In order to arrive at an alternative epistemology, the author conducts an exemplary reconstruction of the securitization of Roma groups in Rome in which material objects and their (dis)placement, like surveillance cameras and fences around state-authorized Roma camps, merge which symbolic constructions of the Roma as dangerous. In this perspective, power is conceptualized as being the prod-

25 Hansen 2011, pp. 55-58.

26 See Buzan/Wæver 2009. 
uct of such complex 'translations' between material, semioticity, human and hon-human agency.

Arguably, this volume falls short of suggesting the 'one' conceptualization of power in dynamics of securitization. Rather, its objective is to probe the grounds for elaborating on alternatives to the, still often encountered, implicit resource-theoretical notion of power in securitization studies - a power that enables strategic actors to securitize, be it through dramatic speech-acts or through less dramatic, but no less effective, professional practices. Developing alternatives to such simplistic view entails confronting the available versions of securitization studies both with conceptual reconstructions - with an 'immanent critique', ${ }^{27}$ as it were - and with historical reconstructions of processes of securitization that point to the limits of current securitization studies' understanding of power.

Finally, the results presented in this volume invite an engagement in research along the following general lines: the relationalities of securitization between different actors, across different discourses and between different scales of power figurations, from local to global; the materialities of the power of securitization, not only with respect to the role of material artefacts and processes in security routines, but also with respect to the materiality of the 'securitizing move' as it crystallizes in different material and medial formats; and the long-term formation of 'grammars of security' (whereby 'grammar' might be too narrow a term, invoking language practices while glossing over other symbolic registers) and their organization into what might be preliminarily called an archive of security. Future archivists of security and securitization, in reconstructing the records, might be better equipped to challenge the ubiquity of 'security' as an allegedly universal concern.

\section{References}

Anderson, Benedict (1998): Nationalism, Identity, and the Logic of Seriality. In: The Spectre of Comparisons: Nationalism, Southeast Asia and the World. London/New York: Verso, pp. 29-45.

27 Cf. Browning/McDonald 2011, pp. 248-251. 
Balzacq, Thierry (2005): The three faces of securitization: political agency, audience and context. European Journal of International relations 11(2): 171-201.

Balzacq, Thierry (2011): A theory of securitization: Origins, core assumptions, and variants. In: Thierry Balzacq (ed.): Securitization Theory: How Security Problems Emerge and Dissolve. London/New York: Routledge, pp. 1-30.

Balzacq, Thierry / Léonard, Sarah / Ruzicka, Jan (2016): Securitization revisited: Theory and cases. International Relations 30(4): 494-531.

Bigo, Didier (2002): Security and immigration: Toward a critique of the governmentality of unease. Alternatives: Global, Local, Political 27(1): 63-92.

Bigo, Didier (2006): Globalized-in-security: The field and the ban-opticon. In: Naoki Sakai/Jon Solomon (eds.): Translation, Biopolitics, Colonial Difference (= Traces. A Multilingual Series of Cultural Theory and Translation, vol 4.). Hong Kong: Hong Kong University Press, pp. 109-155.

Bigo, Didier (2014) Security, IR and anthropology: Encounters, misunderstanding and possible collaborations. In: Catarina Frois / Mark Maguire / Nils Zurawski (eds.): The Anthropology of Security. Basingstoke: Palgrave Macmillan, pp. 189-205.

Browning, Christopher S. / McDonald, Matt (2011): The future of critical security studies: Ethics and the politics of security. European Journal of International Relations 19(2): 235-255.

Buzan, Barry / Wæver, Ole / Wilde, Jaap de (1998): Security. A new framework for analysis. Boulder, Colo.: Lynne Rienner Pub.

Buzan, Barry/Wæver, Ole (2009): Macrosecuritisation and security constellations: reconsidering scale in securitisation theory. Review of International Studies 35: 253276.

Buzan, Barry (2016): The English School: A neglected approach to International Security Studies. Security Dialogue 46(2): 126-143.

Christou, George / Croft, Stuart / Ceccorulli, Michela / Lucarelli, Sonia (2010): European Union security governance: Putting the 'security' back in. European Security 19(3): 341-359.

Conze, Eckart (2012): Securitization. Gegenwartsdiagnose oder historischer Analyseansatz? Geschichte und Gesellschaft 38: 453-467.

Daase, Christopher (2011): Sicherheitskultur - Ein Konzept zur interdisziplinären Erforschung politischen und sozialen Wandels. Sicherheit und Frieden / Security and Peace 29(2): 59-65.

Daase, Christopher (2012): Sicherheitskultur als interdisziplinäres Forschungsprogramm. In: Christopher Daase/Philipp Offermann/Valentin Rauer (eds.): Sicherheitskultur. Soziale und politische Praktiken der Gefahrenabwehr. Frankfurt a.M./New York: Campus, pp. 23-44.

Gros, Frédéric (2015): Die Politisierung der Sicherheit. Vom inneren Frieden zur äußeren Bedrohung. Berlin: Matthes \& Seitz.

Hansen, Lene (2011): Theorizing the image for Security Studies: Visual securitization and the Muhammad Cartoon Crisis. European Journal of International Relations 17(1): 51-74. 
Holbraad, Martin / Pedersen, Morten Axel (eds.) (2013): Times of security: Ethnographic of fear, protest and the future. London/New York: Routledge.

Huysmans, Jef (1998): Security! What do you mean? From concept to thick signifier. European Journal of International Relations 4(2): 226-255.

Junk, Julian (2011): Globale Sicherheitskultur und die „Responsibility to Protect“. Sicherheit und Frieden / Security and Peace 29(2): 95-102.

Munster, Rens van (2005): Logics of Security: The Copenhagen School, Risk Management and the War on Terror. Syddansk Universitet: Political Science Publications 10.

Rollason, Will (2017): Security, otherwise? Anthropology of this Century 19, http://aot cpress.com/articles/security/ (accessed on May 17, 2018).

Stritzel, Holger (2012): Securitization, power, intertextuality: Discourse theory and the translations of organized crime. Security Dialogue 43(6): 549-567.

Vuori, Juha A. (2011): How to Do Security with Words: A Grammar of Securitization in the People's Republic of China. (= Annales Universitatis Turkuensis, Sarja - Ser. B OSA - tomus 336 - Humaniora.) Turku: University of Turku.

Wæver, Ole (1995): Securitization and desecuritization. In: Ronnie D. Lipschutz (ed.): On Security. New York: Columbia University Press, pp. 46-86.

Wæver, Ole (1996): European security identities. Journal of Common Market Studies 34(1): 103-132.

Wæver, Ole (2004): Aberystwyth, Paris, Copenhagen: New 'Schools' in Security Theory and their Origins between Core and Periphery. Paper presented at the annual meeting of the International Studies Association, Montreal, March 17-20, 2004.

Wæver, Ole (2015): The history and social structure of security studies as a practicoacademic field. In: Trine Villumsen Berling / Christian Bueger (eds.): Security Expertise: Practice, Power, Responsibility. London / New York: Routledge, pp. 76106.

Williams, Michael (2003): Words, images, enemies: Securitisation and international politics. International Security Quarterly 47(4): 511-32. 